\title{
Shigemi Sasaki, Le conte d'Apollo et de son lévrier
}

\section{G. Matteo Roccati}

\section{(2) OpenEdition}

\section{Journals}

\section{Édition électronique}

URL : http://journals.openedition.org/studifrancesi/27178

DOI : 10.4000/studifrancesi.27178

ISSN : 2427-5856

\section{Éditeur}

Rosenberg \& Sellier

\section{Édition imprimée}

Date de publication : 31 décembre 2006

Pagination : 574

ISSN : 0039-2944

\section{Référence électronique}

G. Matteo Roccati, «Shigemi Sasaki, Le conte d'Apollo et de son lévrier», Studi Francesi [En ligne], 150 (L | III) | 2006, mis en ligne le 30 novembre 2015, consulté le 08 novembre 2020. URL : http:// journals.openedition.org/studifrancesi/27178; DOI : https://doi.org/10.4000/studifrancesi.27178

\section{Ce document a été généré automatiquement le 8 novembre 2020.}

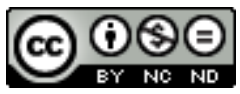

Studi Francesi è distribuita con Licenza Creative Commons Attribuzione - Non commerciale - Non opere derivate 4.0 Internazionale. 


\title{
Shigemi Sasaki, Le conte d'Apollo et de son lévrier
}

\author{
G. Matteo Roccati
}

\section{RÉFÉRENCE}

SHIGEMI SASAKI, Le conte d'Apollo et de son lévrier, «Romania», t. 123, 489-490, 2005, pp.

51-79.

1 Le récit est introduit dans le chapitre XV du Livre de chasse de Gaston Phébus, rédigé entre 1389 et 1391, il est également présent avec des variantes dans le Roman de Tristan en prose. L'article en examine le schéma narratif, la genèse et les sources possibles; il met en lumière l'arrière-plan historique, ou pseudo-historique, qui a présidé à la formation du conte, dont le but est de relier le règne de Tristan à celui de Clovis. 